\title{
The odontal status of the permanent primary molar in a group of children aged between 7 and 15 year-old
}

Statusul odontal al molarului prim permanent la un grup de copii cu vârste cuprinse între 7 şi 15 ani

\begin{abstract}
Adina Magdalena Bunget ${ }^{1}$, Ionela Teodora Dascălu², C. Dăguci ${ }^{3}$, P. Mărăşescu ${ }^{4}$, Felicia Mărăşescu ${ }^{2}$, Marina Amărăscu ${ }^{5}$, Andreea Gabriela Nicola ${ }^{1}$, Mihaela Stan ${ }^{6}$, Iren Moraru ${ }^{7}$, Oana Andreea Diaconu ${ }^{7}$, Edwin Sever Bechir ${ }^{8}$, Cristian Funieru ${ }^{9}$

${ }^{1}$ Disciplina de Prevenţie Orodentară, Universitatea de Medicină şi Farmacie, Craiova, România

${ }^{2}$ Disciplina de Ortodonţie, Universitatea de Medicină şi Farmacie, Craiova, România

${ }^{3}$ Disciplina Sănătate Orală, Universitatea de Medicină şi Farmacie,Craiova, România

${ }^{4}$ Disciplina de Tehnologie a Protezelor Dentare, Universitatea de Medicină şi Farmacie,

Craiova, România

${ }^{5}$ Disciplina de Morfologie şi Semiologie a Sistemului Stomatognat, Universitatea de Medicină şi Farmacie, Craiova, România

${ }^{6}$ Disciplina de Materiale Dentare, Universitatea de Medicină şi Farmacie, Craiova, România

${ }^{7}$ Disciplina de Endodonţie, Universitatea de Medicină şi Farmacie, Craiova, România

${ }^{8}$ Disciplina de Parodontologie, Universitatea de Medicină şi Farmacie, Tg. Mureş, România

${ }^{9}$ Disciplina de Prevenţie Orodentară, Universitatea de Medicină şi Farmacie „Carol Davila“,
\end{abstract}

Bucureşti, România

\begin{abstract}
REZUMAT
Scopul acestui studiu a fost evaluarea prevalenţei cariei dentare la molarul prim permanent la un grup de copii.

Au fost luaţi în studiu un grup de copii cu vârste de 7-15 ani. Copiii au fost examinaţi într-un cabinet dentar şi pentru fiecare pacient a fost analizat statusul odontal al molarilor primi permanenţi, şi a fost calculat indicele DMFT.

Au fost examinaţi 332 de molari primi permanenţi la 83 de copii. Procentul afectării prin carie a molarului prim permanent a fost: $6 \%$ dintre fete şi $12 \%$ dintre băieţi au avut extracţii, $21 \%$ dintre fete şi $51 \%$ dintre băieţi au prezentat molari cu distrucţie coronară mare, 38\% dintre fete şi $66 \%$ dintre băieţi aveau cel puţin un proces carios la molarii primi permanenţi. Prevalenţa cariei dentare creşte cu vârsta, molarii extraşi fiind descoperiţi la copiii din grupa de vârstă 10-15 ani.

Prevalenţa cariei dentare la molarii primi permanenţi este crescută. Studiul relevă un procent crescut al molarilor pierduţi sau cu distrucţii mari coronare la pacienţi cu vârsta sub 15 ani.

Este necesar să se aplice măsuri preventive pentru a îmbunătăţi starea de sănătate orală la copii.
\end{abstract}

Cuvinte cheie: carii, DMFT, primul molar permanent

\begin{abstract}
The aim of the study was to assess the prevalence of dental caries of first permanent molars in a group of children of Craiova.

The sample of the study consisted of 83 children aged 7-15 years. The children were examined in a dental office and for each patient it had been analyzed the clinical status of first permanent molars, and it had been calculated the DMFT index.
\end{abstract}


332 of first permanent molars of 83 children were examined. The percentage of caries damages of first permanent molars was: $6 \%$ of girls and $12 \%$ of boys had extractions, $21 \%$ of girls and $51 \%$ of boys had very damaged molars, $38 \%$ of girls and $66 \%$ of boys had at least one cavity of first permanent molars. The prevalence of caries increases with age, and the extracted molars were found to the children aged $10-15$ years.

The prevalence of first permanent molars caries is high. The study reveals high percentage of damaged and lost molars to the children aged under 15 years.

It is necesary to apply preventive methods in order to improve children's oral health.

Keywords: caries, DMFT, first permanent molar

\section{INTRODUCERE}

În ultimii ani prevalența şi incidența cariei dentare au cunoscut o răspândire foarte variată la nivel global.

Majoritatea studiilor arată o îmbunătăţire a statusului odontal şi parodontal la populaţia țărilor industrializate, mediul cultural şi social al unei regiuni fiind factor ce influențează apariția cariilor dentare $(1,2)$. Reducerea prevalenței cariei dentare se datorează instituirii de programe de prevenţie oro-dentară cu stabilirea unor strategii preventive şi terapeutice adaptate nevoilor populaţiei $(3,4)$.

Caria dentară este una dintre cele mai frecvente afecțiuni ale copilăriei, tratamentul, dar mai ales prevenția acesteia fiind una dintre principalele preocupări ale medicului dentist (5).

Molarii primi permanenți sunt considerați cei mai importanţi dinţi datorită rolurilor multiple pe care le au în dezvoltarea, funcționalitatea şi dinamica întregului aparat dento-maxilar (6). În acelaşi timp sunt şi cei mai vulnerabili dinţi de pe arcade din cauza poziţiei lor, a morfologiei lor coronare şi a erupției precoce în cavitatea orală $(5,7)$.

Riscul crescut de apariţie a cariei dentare la primii molari permanenți, cauzat în mare parte de instituirea deficitară a mijloacelor de igienă, neglijarea vizitelor şi controalelor periodice la cabinetul dentar, duce la pierderea precoce a acestor dinți de pe arcade (8).

Studii efectuate în Nigeria şi Arabia Saudită au arătat o prevalență crescută a cariei dentare la molarii primi permanenţi la copii, şi o rată crescută a extracțiilor la aceşti dinți $(9,10)$.

Prevalența cariei dentare poate fi corelată cu consumul sistemic de fluor, după cum arată studii efectuate în regiuni în care există concentrații crescute de fluor natural în apa de băut (5).

Cele mai multe studii arată o creştere a prevalenței cariei dentare o dată cu înaintarea în vârstă (9).
Întrucât prevalenţa cariei dentare este crescută la molarii primi permanenți la copii cu vârste de 7-8 ani, se impune adoptarea cât mai precoce a unor măsuri de prevenție (11).

\section{MATERIAL ŞI METODĂ}

A fost realizat un studiu statistic pe o perioada de doi ani pe un grup de 83 de copii din Craiova. Copiii au fost împărțiți în funcție de vârstă în două loturi: un grup de copii cu vârsta până în 10 ani, şi celălalt grup cu vârste cuprinse între 10 şi 15 ani.

Criteriile de selecție au cuprins vârsta pacienților, copii având cel puțin un molar prim permanent erupt pe arcade, pacienți cooperanți, copii cu status al sănătăţii general bun.

Fiecare pacient a fost interogat şi examinat, $\mathrm{cu}$ întocmirea unei foi de observație, şi examinare clinică, notându-se statusul odontal al dinţilor temporari şi permanenți. De asemenea, a fost calculat indicele DMFT pentru fiecare pacient, notând numărul de dinți cariați, dinții extraşi ca urmare a evoluției unui proces carios, şi dinţii obturaţi.

Datele au fost înregistrate şi prelucrate statistic cu ajutorul programului Microsoft Excel.

\section{REZULTATE ŞI DISCUŢII}

Dintre cei 83 de pacienți din Craiova luaţi în studiu, 25 au avut vârste sub 10 ani, iar 58 au avut vârste între 10 şi 15 ani. Distribuţia pe sexe a fost 48 de pacienți de sex feminin, un procent de 58\%, şi 35 de pacienți de sex masculin, reprezentând $42 \%$ (Fig. 1).

În ceea ce priveşte numărul de molari primi permanenţi extraşi, doi dintre pacienții de sex feminin au cel puţin un molar extras ( $6 \%$ dintre fete) şi respectiv 3 dintre pacienții de sex masculin $(12 \%$ dintre băieți) (Fig. 2).

G.A.Chukwu şi colaboratorii arată, într-un studiu realizat în Nigeria în 2004 pe un lot de copii, un 
procent de $42 \%$ din totalul extracțiilor efectuate la molari primi permanenți.

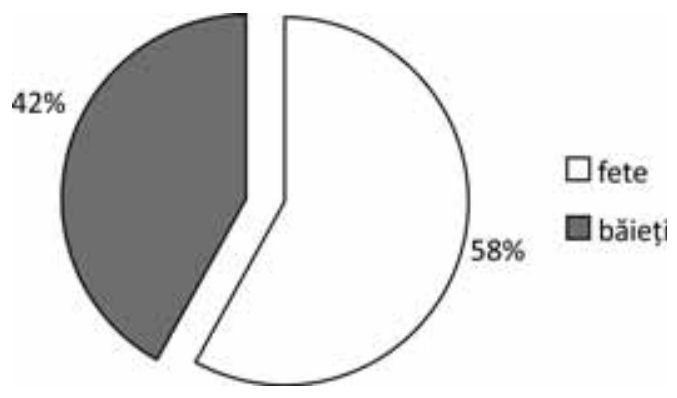

FIGURA 1. Distribuția pe sexe

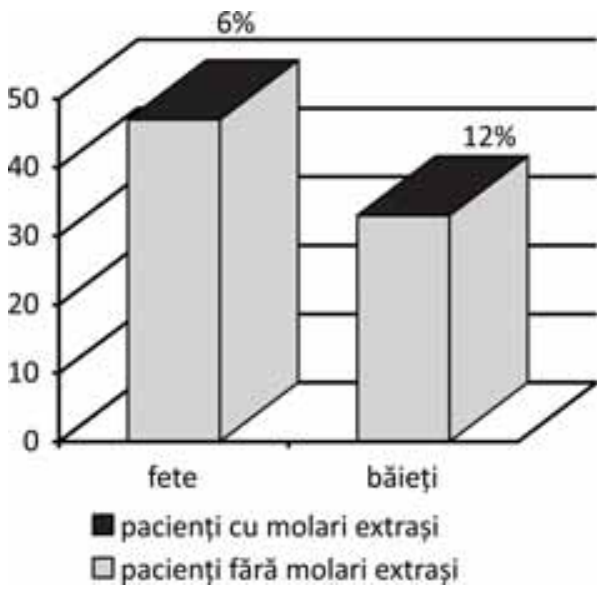

FIGURA 2. Pacienți cu extracții

Din totalul de 332 de molari primi permanenți examinați 11 molari au fost absenți, extraşi ca urmare a evoluției unui proces carios. Din totalul molarilor extraşi, 8 au fost molari de pe hemiarcadele drepte (procent de 72\%). Acest aspect ne poate sugera o igienă necorespunzătoare prin periaj la nivelul hemiarcadelor drepte, întrucât la acest nivel sunt zone cu probleme la periajul dentar pentru dreptaci (Tabelul 1).

De asemenea, rezultatele arată o predominanță a extracțiilor la nivelul arcadelor inferioare (procent de $63 \%$ ), posibil din cauza erupției prelungite a acestor molari, cu stagnarea îndelungată a plăcii bacteriene la nivelul suprafețelor ocluzale (Tabelul 1).

Un studiu asemănător realizat de Anca Maria Răducanu şi colaboratorii în 2009 arată de asemenea o predominanță a extracțiilor la nivelul arcadei inferioare; totuşi, ca distribuție pe hemiarcade, au obținut mai multe extracții la nivelul hemiarcadelor stângi.

Yanagisawa şi colaboratorii, 1981, consideră că erupția îndelungată a molarilor primi inferiori îi face mai vulnerabili la apariţia cariei dentare.
Toți dinții extraşi au fost identificați la pacienții din grupa de vârstă 10-15 ani.

TABELUL 1

\begin{tabular}{|l|c|c|c|c|c|c|c|c|}
\hline \multirow{2}{*}{ vârsta } & \multicolumn{2}{|c|}{16} & \multicolumn{2}{c|}{26} & \multicolumn{2}{c|}{36} & \multicolumn{2}{c|}{46} \\
\cline { 2 - 9 } & $\begin{array}{c}\text { nu- } \\
\text { măr }\end{array}$ & $\%$ & $\begin{array}{c}\text { nu- } \\
\text { măr }\end{array}$ & $\%$ & $\begin{array}{c}\text { nu- } \\
\text { măr }\end{array}$ & $\%$ & $\begin{array}{c}\text { nu- } \\
\text { măr }\end{array}$ & $\%$ \\
\hline Sub 10 ani & 0 & 0 & 0 & 0 & 0 & 0 & 0 & 0 \\
\hline $10-15$ ani & 3 & $27 \%$ & 1 & $9 \%$ & 2 & $18 \%$ & 5 & $45 \%$ \\
\hline
\end{tabular}

84\% dintre molarii primi permanenți studiați au prezentat afectare prin carie. Dintre aceştia 11 au fost molari extraşi (3\%), 58 molari au fost cu distrucții coronare masive sau resturi radiculare (17\%) şi 211 molari au prezentat carii (64\%).

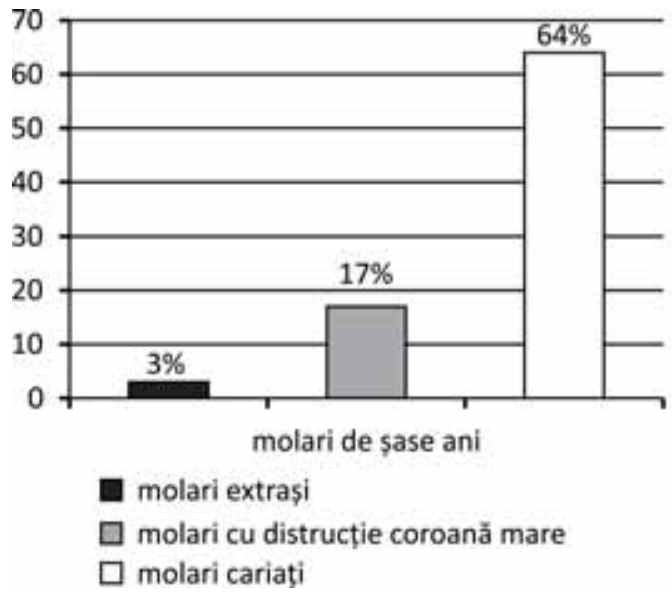

FIGURA 3. Gradul de afectare prin carie

Din totalul pacienților luați în studiu 18 băieți şi 10 fete au prezentat molari primi permanenți sub formă de resturi radiculare sau cu distrucții coronare mari (51\%, respectiv 21\%) (Fig. 4).

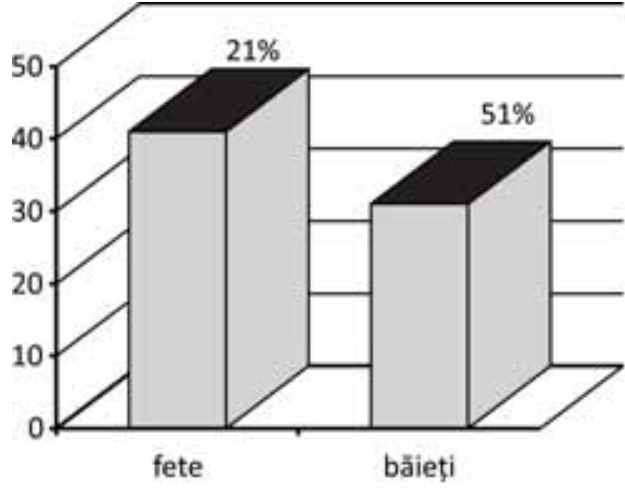

pacienți cu distrucţii coronare mari ale molarilor $\square$ pacienți fără distrucții coronare ale molarilor

FIGURA 4. Pacienți cu distrucții coronare mari

41 dintre copii au prezentat cel puțin o leziune carioasă la unul dintre molarii primi permanenți, $38 \%$ dintre fete şi $66 \%$ dintre băieți (Tabelul 2). 
În privința distribuției pe sexe a afectării prin carie a primilor molari permanenți se observă o predominanță a afectării la băieți (Tabelul 2).

TABELUL 2

\begin{tabular}{|l|c|c|c|c|c|c|}
\hline \multirow{2}{*}{ sex } & \multicolumn{2}{|c|}{$\begin{array}{c}\text { Molari } \\
\text { extrași }\end{array}$} & $\begin{array}{c}\text { Resturi radiculare sau } \\
\text { distrucții mari }\end{array}$ & \multicolumn{2}{|c|}{ carii } \\
\cline { 2 - 7 } & $\mathrm{nr}$ & $\%$ & $\mathrm{nr}$ & $\%$ & $\mathrm{nr}$. & $\%$ \\
\hline fete & 2 & $6 \%$ & 10 & $21 \%$ & 18 & $38 \%$ \\
\hline băieți & 3 & $12 \%$ & 18 & $51 \%$ & 23 & $66 \%$ \\
\hline
\end{tabular}

Statusul odontal al molarilor primi permanenţi a fost studiat şi în Sri Lanka pe un lot de copii, rezultatele arătând doar $11 \%$ dintre molari afectați de carie (S.Warnakulasuriya, 1991).

A fost calculat indicele DMFT la fiecare grupă de vârstă, atât pentru fete, cât şi pentru băieți. Rezultatele arată a valoare medie de 2,18 pentru băieți şi o valoare medie de 2 pentru fete pentru grupa de vârstă sub 10 ani. Pentru grupa de vârstă 10-15 ani s-a obținut o diferență semnificativă între valorile DMFT la băieți, 7,06, şi la fete, 5,5 (p>0,05).

Amariei şi colaboratorii au realizat în 2001 un studiu în Constanța care evidențiază valori de 4,66 pentru indicele DMFT la copii cu vârsta de 12 ani. După aplicarea unor măsuri preventive timp de 6 ani, a scăzut considerabil prevalența cariei în regiunea respectivă (Cristina Nuca şi colab., 2009).

Propunerea OMS în ceea ce priveşte prevalența cariei dentare, pentru anul 2000, a fost ca la vârsta de 5-6 ani 50\% dintre copii să nu prezinte carii, iar pentru vârsta de 12 ani, indicele DMFT să fie sub valoarea 3.

\section{BIBLIOGRAFIE}

1. Kalsbeek H., Verrips G.H.W. Dental caries prevalence and the use of fluorides in different European countries, Journal of Dental Research, vol.69, p.728-732, 1990

2. Marthaler T.M. Caries status in Europe and Prediction of Future Trends, Caries Research, vol. 24, pp 381-386,1990

3. World Health Organization, World Health no1, 1994

4. Oral Health ICMR Bulletin, vol.24,4,1994

5. Vikas C. Desai, Rajendra E. Reddy, Manjula M., Shaik Hussain Saheb, Prevalence of Dental Caries in first and second permanent molars, International Journal of Research in Medical Sciences, 2(2):514-520, may 2014

6. Anca Maria Răducanu, Victor Feraru, Claudiu Herteliu, Mihai Andrei Răducanu, Prevalence of Loss of Permanent First Molars in a Group of Roumanian Children and Adolescents, OHDMBSC, vol. VIII, no3, sept. 2009

7. Milgrom P., Tut O.K. Evaluation of Pacific Islands Early Childhood Caries Prevention Project: Republic of the Marshall Islands. J Public Health Dent. 2009.69(3):201-203.
Comparativ cu alte studii efectuate se poate observa un indice DMFT cu valori mai mari pentru vârsta de 6 ani în România față de alte țări mai dezvoltate (Elisa Mădălina Chirca şi colab., 2015; Baciu D. şi colab., 2015).

Totuşi, în ultimele secole, se poate observa o scădere importantă a prevalenței cariei dentare şi a severităţii afectării prin carie a molarilor la copii în țările dezvoltate dar chiar şi în țări cu o situație socio-economică dezavantajoasă (Silvia Cypriano şi colab., 2005).

\section{CONCLUZII}

Molarii primi permanenți sunt cei mai vulnerabili dinţi de pe arcade, prevalenţa cariei dentare la aceşti dinți crescând odată cu înaintarea în vârstă.

Afectarea prin carie a molarului prim permanent este foarte crescută începând cu primii ani de la erupția pe arcade, astfel încât mulți pacienți adolescenți ajung să aibă deja molari primi permanenți extraşi.

Întrucât prevalența cariei dentare este foarte crescută pentru pacienții cu vaîrste sub 15 ani, se impune adoptarea unor strategii de prevenție a cariei aplicate cât mai precoce.

\section{Notă}

Toți autorii au participat în mod egal la realizarea acestui articol.

Conflict of interest: none declared Financial support: none declared

8. Elisa Mădălina Chirca, Rodica Luca, Dan-Emil Georgescu, The Prevalence of Caries in First Permanent Molar in a Group of School Children Aged 6 to 7 Years in Piteşti, The Publishing House of the Roumanian Academy, supplement 1/2015,4 th ISAA

9. Khalid H.M.Al-Samadani, Mohammad Sami Ahmad, Prevalence of First Permanent Molar Caries in and Its Relationship to the Dental Knowledge of 9-12 year olds from Jeddah, Kingdom od Saudi Arabia, International Scholarly Research Network, ISRN Dentistry, vol 2012, Art ID 391068

10. Chukwu G.A., Adeleke O.A., Danfillo I.S., Otoh E.C. Dental Caries and Extraction of Permanent Teeth in Jos, Nigeria, African Journal of Oral Health, vol.1, no1, pp 31-36, 2004

11. Jin-Dong Wang, Xi Chen, Jo Frencken, Min-Quan Du, Zhi Chen, Dental caries and first permanent molar pit and fissure, Morphology in 7- to 8-year-old children in Wuhan, China, International Journal of Oral Science (2012) 4, 157-160 
12. Yanagisawa, Munemitsu, Studies on the Caries Susceptibility of the first Molars, part 1, J.Nihon Univ. Dent. Asso., 55:23-37, 1981

13. Warnakulasuriya S. Caries Susceptibility of First Permanent Molars and Treatment needs in Sri Lanka children aged 13-16 years in 1986, Community Dental Health, vol.8, no2, pp.167-172, 1991

14. Amariei C., Damasaru E., Gaita A., Totolici I. The prevalence of the orodental diseases in 6- and 12-year-old children from Constanta District. Analele Universitatii Ovidius Constanta 2001; 7(1): 182-184.

15. Baciu D., Dănilă I., Balcos C., Gallagher J.E., Bernabe E. Experienţa cariilor în rândul elevilor români: prevalenţă şi tendinţe 1992-2011. Revista Română de Medicină Dentară, 2015; XVIII(2):97-104

16. Cristina Nuca, Corneliu Amariei, Annerose Borutta, Lucian Petcu, Prevalence and Severity of Dental Caries in 6- and 12-Year-Old Children in Constanta District (Urban Area), Romania, OHDMBSC, Vol. VIII, No. 3, September, 2009

17. Silvia Cypriano, Maria da Luz Rosário de Sousa, Ronaldo Seichi Wada, Evaluation of simplified DMFT indices in epidemiological surveys of dental caries, Rev. Saúde Pública vol.39 no.2 São Paulo Apr. 2005 